\title{
Retention of chromium by modified Al-Bentonite
}

\section{(Retenção de cromo por Al-bentonita modificada)}

\author{
C. Volzone, L. B. Garrido \\ CETMIC (Centro de Tecnología de Recursos Minerales y Cerámica-CIC-CONICET) \\ C.C. 49, Cno. Centenario y 506, (1897) M. B. Gonnet, \\ Prov. Buenos Aires, Argentina \\ volzcris@netverk.com.ar
}

\begin{abstract}
Retention of chromium (III) from a tanning wastewater by modified Al-bentonites was studied. One bentonite from San Juan province, Argentina, was used. Al-bentonite was prepared by contact of bentonite with hydrolyzed $\mathrm{OH}-\mathrm{Al}$ solutions $(0.10 \mathrm{M}$ in $\mathrm{Al})$ for 24 hours. The modified Al-bentonites were obtained by: a) treatment with $0.5 \mathrm{M}$ sodium chloride; b) with $0.5 \mathrm{M}$ sodium chloride adjusted at $\mathrm{pH} \mathrm{8;}$ and c) treatment with an hexametaphosphate solution after sodium addition. Then, the samples were dried at $100{ }^{\circ} \mathrm{C}$ and heated at $500^{\circ} \mathrm{C}$. The chromium (III) retention by samples was carried out in batch system putting in contact the material with a $2000 \mathrm{ppm}$ Cr tannery waste at different times. The retained chromium was characterized by analyzing the supernatant using UV-visible spectroscopy. The different chromium retention was correlated with structural characteristics of the solids.
\end{abstract}

Keywords: chromium retention, Al-bentonite, tanning wastewater.

\section{Resumo}

Foi estudada a retenção de cromo (III) de águas residuais por meio de Al-bentonitas modificadas. Foi usada uma bentonita da província de San Juan, Argentina. As bentonitas-Al forma preparadas colocando-as em contato com soluções $(0,10 \mathrm{M}$ Al) hydrolizadas de $\mathrm{OH}$-Al durante 24 horas. As bentonitas-Al modidicadas foram obtidas por meio de: a) tratamento com cloreto de sódio 0,5 M; b) com cloreto de sódio 0,5 M sodium com pH ajustado para 8; e c) tratamento com uma solução de hexametafosfato após a adição de sódio. As amostras foram então secas a $100{ }^{\circ} \mathrm{C}$ e aquecidas a $500{ }^{\circ} \mathrm{C}$. A retenção do cromo (III) pelas amostras foi feita em lotes colocando o material em contato em diferentes tempos com um resíduo contendo 2000 ppm de cromo. O cromo retido foi caracterizado por meio de análise do sobrenadante usando espectroscopia UVvisível. As diferentes retenções de cromo foram correlacionadas com características estruturais dos sólidos.

Palavras-chave: retenção de cromo, Al-bentonita, águas residuais.

\section{INTRODUCTION}

Many industrial wastewater contain heavy metals (e.g. Pb, $\mathrm{Cr}, \mathrm{Hg}, \mathrm{Cd}$, etc. ). Previous works indicate that natural clays retain chromium from solution. The amount of retained $\mathrm{Cr}$ is mainly a function of the clay types and the polymerization states of the chromium species in solution $[1,2]$.

The reaction of $\mathrm{Al}_{13}$ interlayered smectite with inorganic and organic anions was previously summarized [3,4]. The Al polymers in the interlayer are positively charged, the net positive charge decrease with increasing $\mathrm{pH}$, and form $\mathrm{Al}-\mathrm{OH}$ anion complexes or basic salts with counteranions [3, 4]. Thus, depending on the anion charge, the $\mathrm{Al}-\mathrm{OH}$ anion complexes will have a positive charge density lower than that of the intercalated Al species [4]. Therefore, the use of this material as adsorbent for cations from aqueous environments is possible.

In this work, the adsorption properties of a modified $\mathrm{Al}$ interlayered bentonite were examined. Several materials were prepared after treatment of an hydroxi-Al bentonite with $\mathrm{NaCl}$, $\mathrm{NaCl}$ at $\mathrm{pH} 8$ and Na-hexametaphosphate solution. The removal of $\mathrm{Cr}$ from a tanning wastewater solution by using modified Al-bentonites were determined and related with adsorbent structural properties.

\section{MATERIALS AND METHODS}

The sample used in this study was a bentonite from San Juan province, Argentine (C). It is constituted by dioctahedral smectite and small amount of quartz as impurity. The smectitic species present in this sample were Cheto montmorillonite and beidellite [5]. The bentonite sample was dispersed in distilled water $(10 \mathrm{wt} \%)$ and the $\mathrm{OH}-\mathrm{Al}$-solution was added slowly with stirring. Hydroxy-Aluminum solution $(0.10 \mathrm{M}$ in $\mathrm{Al})$ was prepared by dilution of the commercial concentrate solution $(6.0 \mathrm{M})$ and aged seven days at room temperature. The amount of $\mathrm{Al}$ added was 1000 meq Al per 100 gram of bentonite. After 24 hours in contact the solids were separated and washed several times in order to remove the electrolyte excess (Al-C). The intercalated $\mathrm{OH}-\mathrm{Al}$ bentonite previous washing was separated in different portions and treated as follow: a) with $0.5 \mathrm{M} \mathrm{NaCl}$ and after washing by distilled water (Al-CNa); b) similar to a) but $0.5 \mathrm{M} \mathrm{NaCl}$ was adjusted at $\mathrm{pH} 8(\mathrm{Al}-\mathrm{CNa} 8)$; c) similar to 
a) with further addition of HMP solution (Al-CNaH). All prepared samples were washed, dried at $100{ }^{\circ} \mathrm{C}$ and calcined at $500{ }^{\circ} \mathrm{C}$ previous to retention chromium analysis.

The natural and modified samples were characterized by X-ray diffraction (XRD), using a Phillips 3020 diffractometer at $40 \mathrm{~kW}$ and $20 \mathrm{~mA}$. The diffractograms were performed on the total samples from $3^{\circ}$ to $70^{\circ}$ at $1^{\circ} \% \mathrm{~min}$.

The chromium (III) retention by the samples were carried out in batch system putting the material into contact with a 2000 ppm Cr tannery wastewater. The ratio of solid/liquid was of $5.0 \mathrm{wt} / \mathrm{vol} \%$. The retained chromium by the solid was calculated by the difference between the chromium of the original solution and the chromium of the supernatant using a Hewlett Packard Model 8453 spectrophotometer. The absorbance at $419 \mathrm{~nm}$ was measured.

\section{RESULTS AND DISCUSSION}

Characteristics of samples and the tanning wastewater solution.

Fig. 1 shows the X-ray diffraction patterns of the original sample, Al-bentonite (Al-C) and modified Al-bentonites. The DRX pattern of the Al-C sample shows a high and well-defined 001 reflexion at $19.1 \AA$. Both $\mathrm{Al}-\mathrm{CNa}$ and $\mathrm{Al}-\mathrm{CNa} 8$ samples showed high d(001) peaks with a similar basal spacing to that of $\mathrm{Al}$ bentonite. HMP treatment $(\mathrm{Al}-\mathrm{CNaH})$ produced a basal spacing reduction from 19.1 to $15.0 \AA$ and broadening of the peak (Fig. 1) indicating high degree of structural disorder probably due to $\mathrm{Al}$ extraction and partial replacement of $\mathrm{Al}$ in the interlayer by $\mathrm{Na}$.

The DRX pattern of Al-C also exhibited a small $4.85 \AA$ peak, which was attributed to the presence of gibbsite [6]. The relative intensity of the $4.85 \AA$ peak varied with the treatments.

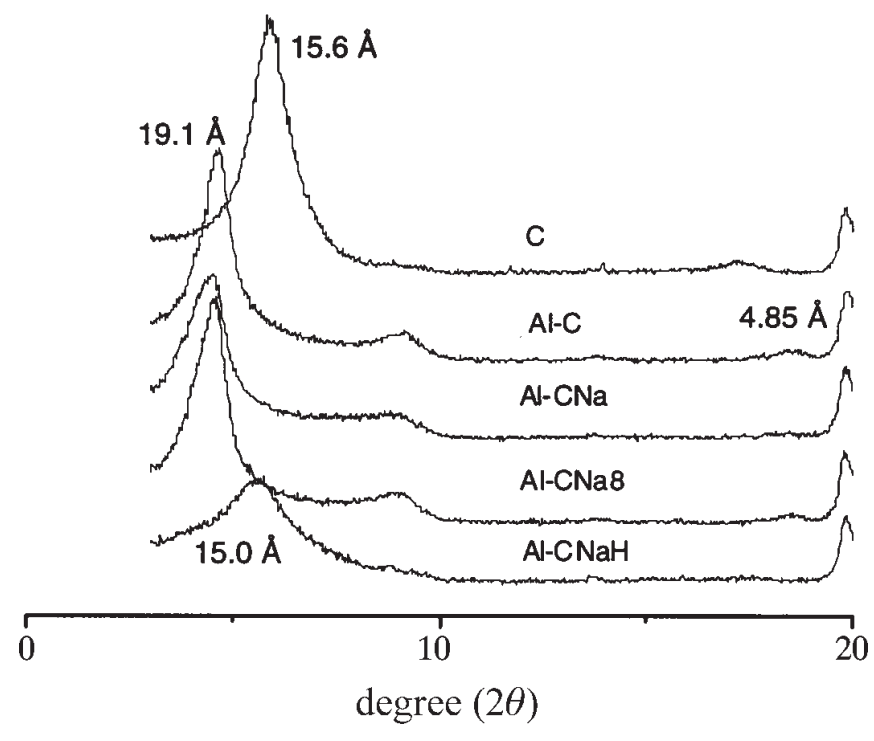

Figure 1: DRX patterns of powdered original, Al-bentonite and modified $\mathrm{Al}$ bentonites.

[Figura 1: Difratogramas de raios $X$ de pós da bentonita-Al e da bentonita-Al modificada.]
It was absent after the $\mathrm{NaCl}$ treatment $(\mathrm{Al}-\mathrm{CNa})$ and after $\mathrm{HMP}$ addition (Al-CNa-H). The treatment with $\mathrm{NaCl}$ at $\mathrm{pH} 8$ (Al-CNa8) produced a slight decrease in intensity compared to that of the Al-bentonite.

Fig. 2 shows the X-ray diffraction patterns of the original bentonite, Al-bentonite and modified Al-bentonites after heating at $500{ }^{\circ} \mathrm{C}$. The interlayer spacing of the original bentonite, $15.6 \AA$, (Fig. 1) collapsed to $9.55 \AA$ After heating (Fig. 2). A slight decrease in intensity and broadening of $\mathrm{d}(001)$ peak regarding to the uncalcined samples were observed for $\mathrm{Al}$ bentonite (Al-C) and modified $\mathrm{Al}$ bentonites, due to dehydroxylation of the pillar

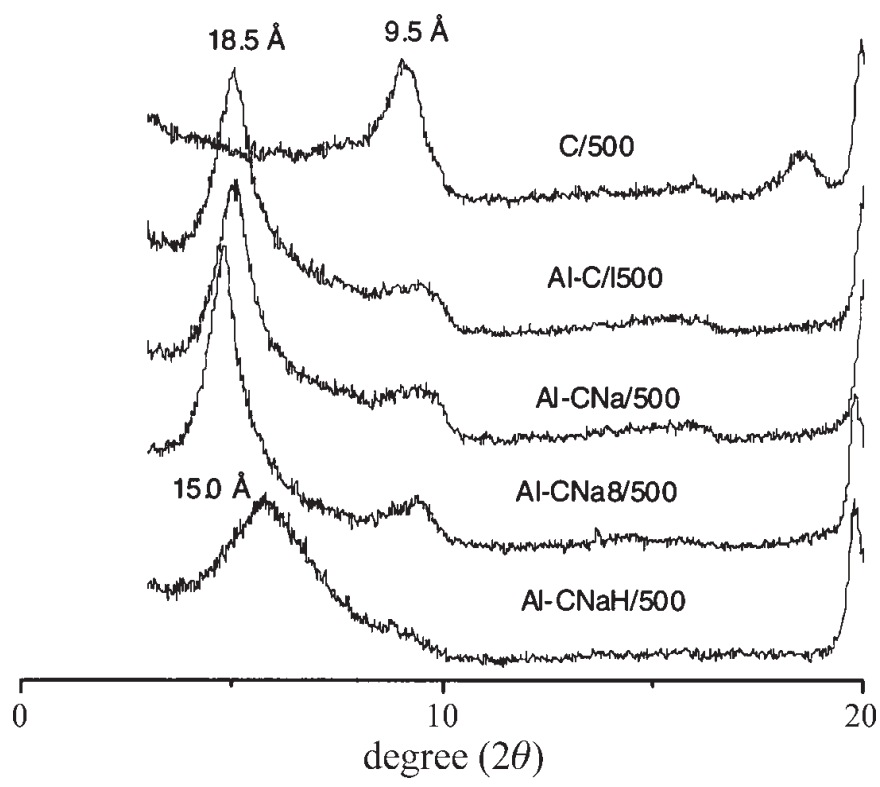

Figure 2: DRX patterns of powdered original, Al-bentonite and modified Al-bentonites heated at $500{ }^{\circ} \mathrm{C}$.

[Figura 2: Difratogramas de raios $X$ de pós da bentonita-Al original e bentonita-Al modificada aquecidas a $500{ }^{\circ} \mathrm{C}$.]

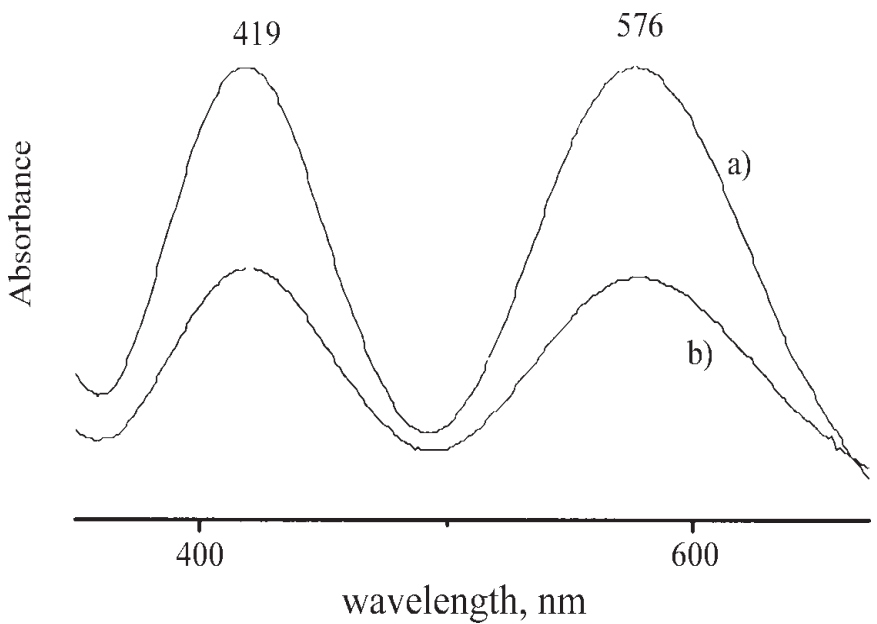

Figure 3: Adsorption spectra: (a) 2000 ppm Cr tanning wastewater solution; (b) supernatant after using $\mathrm{Al}-\mathrm{CNaH}$ bentonite as adsorbent of chromium.

[Figura 3: Espectros de adsorção: (a) solução de água residual com 2000 ppm de cromo; (b) sobrenadante após uso de bentonita- Al-CNaH como meio adsorvente de cromo.] 
Fig. 3a shows the visible spectrum of tanning wastewater containing $2000 \mathrm{ppm} \mathrm{Cr}$. The spectrum showed two bands at 419 and $576 \mathrm{~nm}$. The peak intensities ratio and position of the two bands depend of the exhaustion degree of the original agent salt for tanning (basic chromium sulfate), which has two bands situated at 410 and $575 \mathrm{~nm}$.

These two bands appeared in the spectra of the supernatant solutions using the modified Al-bentonites as adsorbents. For a comparison, Fig. $3 \mathrm{~b}$ shows the spectrum of the supernatant after contacting the modified Al-bentontie with the tanning wastewater.

Retention of Cr by untreated, Al-bentonite and modified Al bentonites dried at $100{ }^{\circ} \mathrm{C}$.

Fig. 4 a) shows the $\mathrm{Cr}$ retention by $\mathrm{C}$ bentonite after drying at $100{ }^{\circ} \mathrm{C}$. About $6.5 \mathrm{mg} \mathrm{Cr} / \mathrm{g}$ was adsorbed after 1 day and the amount of $\mathrm{Cr}$ retained increased to $7.8 \mathrm{mg} \mathrm{Cr} / \mathrm{g}$ after 14 days in contact. $\mathrm{Cr}$ ions may be retained by a cation exchange mechanism due the high cation exchange capacity (CEC) of the bentonite. The same Figure also shows that the amount of retained $\mathrm{Cr}$ on $\mathrm{Al}$-bentonite was lower than that on the untreated clay. Fig. 1 shows that basal spacing expanded to $19.1 \AA$ after intercalation. However, $\mathrm{Al}$ intercalation generally reduced the $\mathrm{CEC}$ of the bentonite as $\mathrm{Al}$ complexes in the interlayer remained positively charged. Therefore, high electrostatic repulsion between positively charged $\mathrm{Al}-\mathrm{OH}$ groups at the surface and $\mathrm{Cr}$ ions in solution prevented high $\mathrm{Cr}$ retention.

The curve of $\mathrm{Cr}$ retention as a function of time (Fig. 4) shows that the amount of retained $\mathrm{Cr}$ by the modified Al-bentonite with $\mathrm{NaCl}$ treatment (Al-CNa) was significantly enhanced. XRD pattern of this sample was similar to that of Al-C bentonite indicating that the amount of $\mathrm{Al}$ interlayered complexes was nearly the same. In addition, the $4.85 \AA$ reflexion of the gibbsite was absent.

The $\mathrm{NaCl}$ treatment displaced most of exchangeable $\mathrm{Al}$ monomers and small polymers [7] and consequently low amount of $\mathrm{Al}$ hydroxide was formed during washings.

Less gibbsite formation favored chromium retention. Treatment of $\mathrm{Al}$ bentonite with $\mathrm{NaCl}$ solution at $\mathrm{pH} 8$ slightly improved $\mathrm{Cr}$ adsorption capacity (Fig. 4a). The DRX pattern of the $\mathrm{Al}-\mathrm{CNa} 8$ sample showed a high d(001) peak with a basal spacing similar to that of sample Al-CNa. However, the relative intensity of the $4.85 \AA$ peak increased probably due to high $\mathrm{pH}$ reduced the exchangeability of $\mathrm{Al}$ species that may control the formation of $\mathrm{Al}$ hydroxides. For the $\mathrm{Al}-\mathrm{CNa} 8$ sample, the amount of retained $\mathrm{Cr}$ slightly increased with respect to that for the Al-CNa sample. Low electrostatic repulsion resulting from the additional negative charge neutralization of the retained $\mathrm{Al}$ species, improving the $\mathrm{Cr}$ retention capacity by this sample.

Fig. 4 shows that the amount of retained $\mathrm{Cr}$ by the $\mathrm{AlCNaH}$

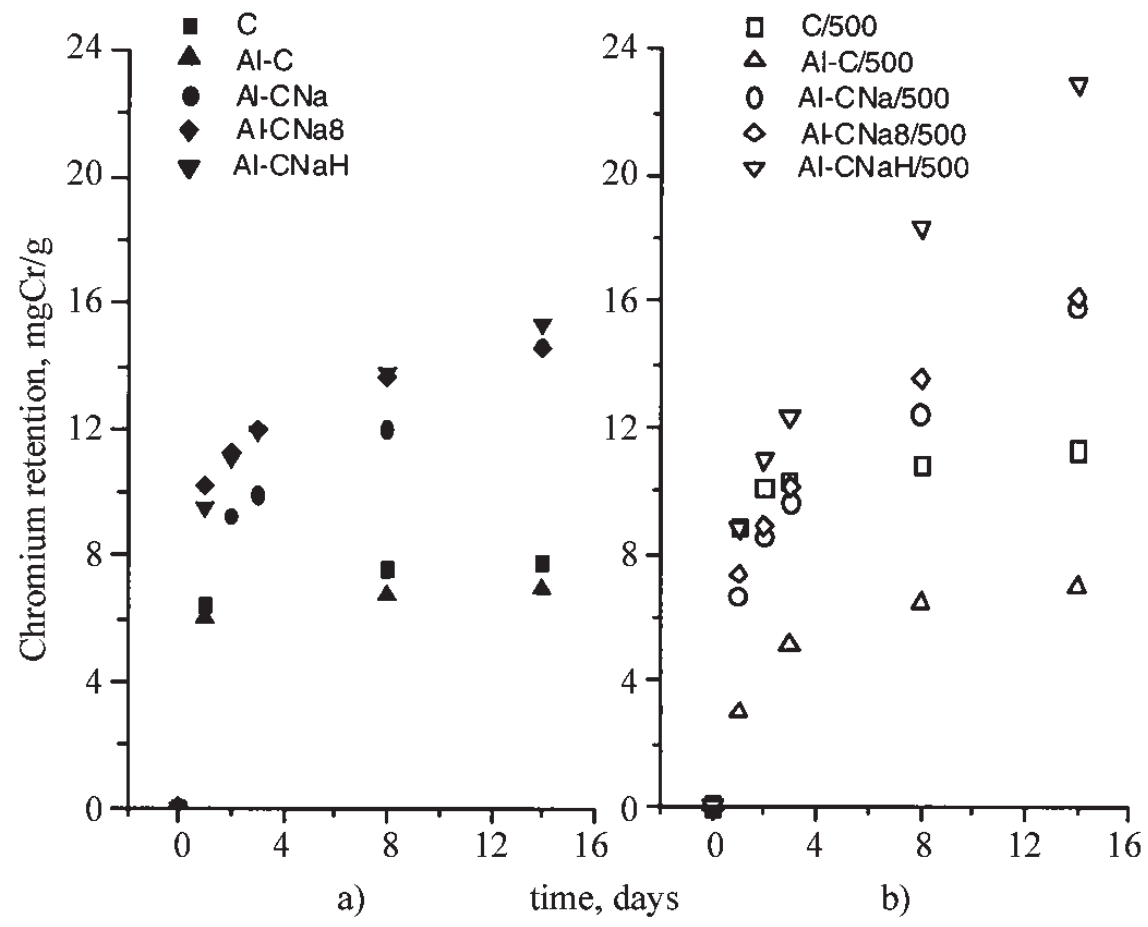

Figure 4: Amount of retained $\mathrm{Cr}$ as a function of time for untreated bentonite, Al-bentonite and modified Al-bentonites. Retention using samples: a) dried at $100{ }^{\circ} \mathrm{C}$; b) after heated at $500{ }^{\circ} \mathrm{C}$.

[Figura 4: Quantidade de cromo retido em função do tempo para as bentonitas não tratada, bentonita-Al e bentonita-Al modificada. Retenção usando amostras: a) seca a $100{ }^{\circ} \mathrm{C}$; b) após aquecimento a $500{ }^{\circ} \mathrm{C}$.] 
sample is similar to that of Al-CNa8. HMP addition produced some structural modifications in the Al-CNa sample. Low basal spacing and broadening indicated less amount and poor ordered $\mathrm{Al}-\mathrm{OH}$ complexes in the interlayer than that present in well ordered Al-CNa bentonite. As the structural disorder increased more Al-OH groups developed on the surface [4]. These groups were available for reaction with HMP. Modified Al bentonite with HMP probably became less positively charged at low $\mathrm{pH}$ and consequently was better adsorbent for chromium than modified $\mathrm{Al}$ bentonite with $\mathrm{NaCl}$. Also, the improvement in $\mathrm{Cr}$ retention may possibly related to the formation of aluminumphosphate compound.

Retention of Cr by untreated, Al-bentonite and modified Al bentonites heated at $500{ }^{\circ} \mathrm{C}$

Fig. 4b shows that $\mathrm{Cr}$ retention for $\mathrm{Al}-\mathrm{CNaH}$, was significantly affected by heating at $500{ }^{\circ} \mathrm{C}$. After heating, the amount of retained $\mathrm{Cr}$ increased from 15 to $23 \mathrm{mgCr} / \mathrm{g}$ after 14 days in contact.

Structural properties were similar to those corresponding to the unheated samples (Figs. 1 and 2). However, removal of adsorbed and interlayered water; and dehydration of Alphosphate compounds favored the availability of active sites for $\mathrm{Cr}$ retention.

\section{CONCLUSIONS}

The amount of retained $\mathrm{Cr}$ by dried samples increased in the following order Al-C $<\mathrm{Al}-\mathrm{CNa}<\mathrm{Al}-\mathrm{CNa} 8=\mathrm{Al}-\mathrm{CNaH}$. Adsorption capacity increased due to the combined effect of the reduction in the $\mathrm{Al}$ exchangeable content and subsequent neutralization of retained Al by alkalization or by HMP addition.

The retention of $\mathrm{Cr}$ by modified Al-bentonite with HMP after heating at $500{ }^{\circ} \mathrm{C}$ increased 3 times with respect to the original bentonite.

Like other complexing agents, HMP anion promoted structural disorder in Al-bentonite. Therefore, more Al-OH groups developed on the surface than that present in well ordered $\mathrm{Al}$ bentonite. These groups were available for reaction with HMP. After heating at $500{ }^{\circ} \mathrm{C}$ structural properties remained unchanged but dehydration of an external $\mathrm{Al}$ phosphate possibly occurred. High amount of retained Cr may be related to the presence of surface phosphate groups.

\section{REFERENCES}

[1] C. Volzone, Mater. Chem. and Phys. 47 (1997) 13.

[2] C. Volzone, in: Catalizadores y Adsorbentes Iberoamericanos para la Remoción de Metales Pesados en Efluentes Industriales (G. Rodríguez Fuentes y P. Avila García, eds). CYTED, Madrid, España. $1^{\text {ra }}$ Edición, 2000. ISBN: 84931538-3-4, pp 83-90.

[3] P. M. Huang, A. Violante, in: Interactions of soils minerals with natural organics and microbes (P. M. Huang \& M. Schitzer, eds.) SSSA Spec. Publ. 17. Soil Science Society of America, WI. (1986) 159.

[4] P. H. Hsu, in: Minerals in soil environments, $2^{\text {nd }}$ ed. (J.B. Dixon and S.W. Weed, eds.). Soil Science Society of America, WI. (1989) 331.

[5] C. Volzone, L. B. Garrido, Applied Clay Science 6 (1991) 143. [6] C. Volzone, L. B. Garrido, Clay Minerals 35 (2001) 115.

[7] P. H. Hsu, Clays and Clay Minerals 40 (1992) 300.

(Rec. 18/05/02, Ac. 09/09/02) 